\title{
Compiling lightning counts for the UK land area and an assessment of the lightning risk facing UK inhabitants
}

\author{
Derek M. Elsom ${ }^{1,3}$, Sven-Erik Enno ${ }^{2}$, Andrew Horseman ${ }^{2}$ and Jonathan D.C. Webb ${ }^{3}$ \\ ${ }^{1}$ Faculty of Humanities \& Social Sciences, Oxford Brookes University, Oxford \\ 2 Observations, Met Office, Exeter \\ ${ }^{3}$ Thunderstorm Division, Tornado and Storm Research Organisation, Oxford
}

Key words: analysis, ATDnet, lightning risk, synoptic, thunderstorms, weather and humanity

\begin{abstract}
New estimates of lightning counts from the Met Office ATDnet system are obtained for the 'UK land area' and compared with those currently available for the 'UK service area' (which includes Republic of Ireland and surrounding seas). Annual counts average $38 \%$ of those in the 'UK service area'. Case studies of thundery periods highlight daily differences. The new annual counts offer a more accurate estimate of the lightning risk facing the UK population. For the period 2008-2016, one lightning death occurred, on average, per 59,000 lightning counts and one person was either killed or injured per 4,000 to 5,000 counts.
\end{abstract}

\section{Introduction}

The lightning risk perceived by most people in the United Kingdom (UK), in terms of the number of lightning strikes to which they and the country are subjected in any time period, is strongly influenced by media headlines. Following a day of severe thunderstorms, the media grab the attention of their readers and viewers with headlines such as "Record 110,000 lightning bolts strike during superstorms" (The Telegraph, 29 June 2012) "Britain zapped by 50,000 lightning bolts" (Daily Star, 24 July 2013), "36,000 lightning strikes in 24 hours and more to come" (Netweather, 19 July 2014), "As many as 19,525 lightning strikes in the UK over 34 hours" (BBC, 2 July 2015) and "Up to 30,000 lightning strikes recorded last night" (QWeather, 4 July 2015). Meteorological agencies may report lightning counts for exceptional thunderstorm days and these may then be repeated in news and social media outlets. For example, the Met Office (2012) reported "over 50,000 strikes on 28 June 2012" and MeteoGroup (2015) tweeted "50,000 lightning strikes across/around the UK in 12 hours" on 4 July 2015.

However, the lightning totals quoted are not simply counts of lightning detected over the UK but may include lightning discharges occurring over the surrounding seas and oceans, the Republic of Ireland, part of northern France, western Belgium and western Netherlands. This area is referred to as the 'UK service area'. So how do the lightning counts for this broad area compare to the actual number of cloud-to-ground lightning strikes which constitute the risk to UK inhabitants, their homes, work places and property and which may cause disruption to services such as electricity supplies and communication systems?

This study employs data from the Met Office lightning location network, Arrival Time Difference Network (ATDnet) and aims to compile more realistic lightning counts for the UK which include only lightning detected over land areas of the UK and excludes 
those over the surrounding seas, the Republic of Ireland and continental Europe. It assesses the differences in lightning counts between the 'UK service area' and the 'UK land area' using monthly and annual periods as well as case studies of exceptional thunderstorm days (Figure 1). The detection method used by ATDnet is explained and its detection efficiency is reviewed. Finally, the new annual 'UK land area' lightning counts are employed to provide an estimate of the risk of being injured or killed by lightning in the UK.

\section{Figure 1}

ATDnet lightning fixes for the 'UK service area' for the 96-hour period from the 17-20 July 2014. Lightning fixes which occur within the 'UK land area' are shown in blue to highlight that much activity lies outside this area and does not pose a risk to the UK

population.

\section{Current lightning counts cover a much broader area than the UK}

A lightning discharge is termed a "flash" and each flash may comprise several "strokes". Around $80 \%$ of all negative lightning flashes comprise more than one stroke, with three to five strokes per flash being common (Uman, 2008). ATDnet detections, referred to as "fixes", correspond to cloud-to-ground lightning return strokes or powerful cloud lightning pulses (Enno et al., 2016). If required, fixes could be later grouped into flashes on the basis of predefined spatial and temporal criteria.

It often happens that different strokes within the same ground flash have different ground contact (strike) points. Stall et al. (2009) found that about half of the negative cloud-to-ground flashes they studied struck the ground in more than one place. Thus, flash data significantly underestimates the actual number of ground strikes. Although fix data may include some strokes in a ground flash which follow exactly the same path and hit the same place, they may be preferred in lightning risk studies as fix data reflects all potential ground strike points, each of which has the capability of causing injury or even death. For example, Elsom et al. (2016) suggests that, on 5 July 2015, two people on separate mountain peaks, $1.7 \mathrm{~km}$ apart, in the Brecon Beacons of south Wales, may have been killed by a single 'forked' lightning flash that had ground termination points on both peaks.

ATDnet continuously records lightning fixes in Europe, Northern Africa, and northern parts of the Atlantic Ocean. For the convenience of the Met Office and other meteorological agency forecasters (for public safety), modellers and other data users (electricity power generation and distribution companies, aviation industry, farmers, insurance companies), the location of lightning fixes are shown on maps, and totals derived, for the 'UK service area' (Figure 1). This area is currently delineated by $49^{\circ} \mathrm{N}$ to $63^{\circ} \mathrm{N}$ and $12^{\circ} \mathrm{W}$ to $2^{\circ} \mathrm{E}$ (although previous delineations have included $49^{\circ} \mathrm{N}$ to $61^{\circ} \mathrm{N}$ and $13^{\circ} \mathrm{W}$ to $5^{\circ} \mathrm{E}, 48^{\circ} \mathrm{N}$ to $61^{\circ} \mathrm{N}$ and $12^{\circ} \mathrm{W}$ to $5^{\circ} \mathrm{E}$, and $47^{\circ} \mathrm{N}$ to $63^{\circ} \mathrm{N}$ and $16^{\circ} \mathrm{W}$ to $5^{\circ} \mathrm{E}$ ). Maps of ATDnet lightning fixes, updated every 15 minutes, are available to the public from various websites such as Netweather (2017). When the media cite total lightning counts for the nation, they cite them for the 'UK service area' and no qualification is usually offered that the totals refer to an area much larger than the UK. By highlighting the significant difference between lightning counts 
for the 'UK service area' and the 'UK land area', this paper will highlight the importance of citing 'UK land only' lightning counts in their reporting.

\section{ATDnet lightning detection network}

Lightning discharges are powerful impulsive sources of electromagnetic energy over a wide bandwidth (from gamma rays and X-rays through optical/visible to microwaves and radio waves). Significant radiated electromagnetic power is emitted from a few $\mathrm{Hz}$ to several hundred $\mathrm{MHz}$, with the bulk of the energy radiated in the frequency bands less than $30 \mathrm{kHZ}$ (Rodger et al., 2004). Passive lightning location methods rely upon the energy released by the lightning discharge, acoustically (thunder), optically (lightning channels) and electromagnetically. Many automated lightning location systems with multiple spatially-separated sensors focus on detecting electromagnetic radiation within a frequency range from a few $\mathrm{kHz}$ to a few hundred $\mathrm{kHz}$ as this is the frequency range in which most of the lightning return stroke is radiated (Uman, 2008).

The Met Office ATDnet lightning detection system detects VLF (Very Low Frequency) lightning-produced electric fields known as radio atmospherics (atmosferics) or, simply 'sferics' (Rakov and Uman, 2003) centred around $13.7 \mathrm{kHz}$. The earlier ATD system used a detection frequency of $9.76 \mathrm{kHz}$ (Lee, 1990) but this was increased to $13.7 \mathrm{kHz}$ with the introduction of ATDnet because there were sporadic transmissions in the Indian Ocean at $10 \mathrm{kHz}$ which prevented the use of 10 kHz for operations (Gaffard et al., 2008; Nash et al., 2006). Since the VLF band of energy is trapped between the earth and the lower boundary of the ionosphere, lightning-generated VLF sferics have long propagation paths over the horizon via interactions with the ionosphere. Indeed, they can circle the globe without too much attenuation (Uman, 2008). This surface-ionosphere passageway is known as the "waveguide" and the sferic waveforms can travel in the waveguide in a similar way to light travelling within a fibre optic cable (Met Office, 2015).

As the ATDnet system detects VLF sferics at very long distances it is described as a long-range lightning detection system (Gaffard et al., 2008). Said (2017) outlines details of the ATDnet system and other long-range lightning locating systems. The ATDnet currently employs a network of 10 automated sensors (outstations), located in and around Europe although other outstations exist for development purposes (Figure 2). To locate a lightning discharge, each sferic waveform has to be detected by a minimum of four sensors. Each sferic waveform has its own characteristic shape when digitised (due to the different ways electric charge breaks down in each particular lightning stroke event) and this unique waveform shape is used to identify each lightning stroke arriving at the different network sensors. The differences in the sferic waveform arrival time at each of the sensors, whose arrival times are timed to better than a millionth of a second, are correlated by a central computer at the Met Office in Exeter to determine the location of the lightning stroke, using the Arrival Time Difference (ATD) technique (Met Office, 2015).

Figure 2

ATDnet's network of ten operational sensors (outstations). Outstation codes: AKR = Akrotiri, CRO = Croatia, ESK - Eskdalemuir, EXE3 = Exeter, GIB = Gibraltar, HEL $=$ Helsinki, KEF $=$ Keflavik, NOR $=$ Norderney, $\mathrm{PAY}=$ Payerne, $\mathrm{VAL}=$ Valentia 


\section{ATDnet flash detection efficiency}

ATDnet has been operating since 2008 and is an updated version of the original innovative, low-cost ATD system which began operating in November 1987 and became an automated system from 2000 (Keogh et al., 2006; Lee, 1986a, 1986b, 1989, 1990; Nash et al., 2006). The initial maximum detection rate was only 400-500 flashes per hour (Lee, 1986b). This increased significantly to 12,000 flashes per hour by 2006 but the problem of network saturation, receiving more data than could be handled (Keogh et al., 2006), reduced its detection efficiency during the summer on days of frequent and extensive thunderstorms (Keogh et al., 2006). The introduction of ATDnet in 2008 increased the detection limit to more than 200,000 flashes per hour resulting in no difference in detection efficiency between summer and winter (Keogh et al., 2006).

The ATDnet system was optimised for detecting the all-important cloud-to-ground lightning strokes and flashes rather than cloud lightning (inter-cloud and intra-cloud lightning). ATDnet predominantly detects sferics created by cloud-to-ground lightning return strokes, as the energy and polarisation of sferics created by such strokes mean that they can travel more efficiently in the earth-ionosphere waveguide (Anderson and Klugmann, 2014). In addition, ATDnet outstations use vertical whip antennas that are more sensitive to sferics with vertical polarisation (Figure 3 ). This means that some cloud lightning flashes are also detected at close range to the sensors because their vertical parts emit sferics similar to those generated by cloudto-ground strokes. Cloud lightning flashes may produce spectacular brightening of the sky but do not pose a direct threat to people on the ground and their daily lives (although they are a hazard for aircraft).

Figure 3

ATDnet outstations use vertical whip antennae that are more sensitive to sferics with vertical polarisation. ATDnet sensor in Keflavik, southwest Iceland (copyright: Met Office)

On the basis of comparisons against short-range lightning location systems (Poelman et al., 2013a), optical observations (Poelman et al., 2013b) and lightning mapping arrays (Enno et al., 2016) ATDnet is capable of detecting around $90 \%$ of cloud-to-ground and up to $25 \%$ of cloud lightning flashes in Europe, including the UK. Note that flash detection efficiency is normally higher than stroke detection efficiency as a multi-stroke flash is detected even if only one of its strokes is detected. Thus, $90 \%$ cloud-to-ground flash detection efficiency means that the percentage of ground strike points that remain undetected is above $10 \%$ because, as explained earlier, a flash may have more than one ground strike point. The nondetection of about $10 \%$ of cloud-to-ground flashes may be due in part to some return strokes that constitute the flash being too small in current and radiated electromagnetic fields to be detected. For example, return strokes with peak currents below 5 to 10kA are usually too weak to be detected (Uman, 2008). 
Another factor affecting detection efficiency are diurnal variations in the height of the ionosphere, interfering with propagation paths and apparent velocity of VLF sky waves (Anderson and Klugmann, 2014; Gaffard et al., 2008; Poelman et al., 2013a, $2013 \mathrm{~b}$ ). ATDnet is tuned for daytime VLF propagation conditions and is around 15 to 20 per cent less sensitive at night. The impact of modal interference is stronger at night when there are clear bands of destructive nighttime interference at certain distances around outstations. In these bands, sferics are seriously distorted due to modal interference between the sky wave modes 1 and 2 which are reflected from the ionosphere once and twice, respectively. Distorted sferics may cause the fix location process to fail as the assumption that the shape of sferics of the same stroke is similar at all outstations is no longer valid. The overall impact of nighttime modal interference to ATDnet detection efficiency is somewhat limited as the majority of cloud-to-ground lightning activity occurs during the day (Blakeslee et al., 2014; Chronis et al., 2015).

Some fixes are rejected by ATDnet quality control as their signal quality reported by outstations or location error computed by ATDnet central processing does not meet predefined threshold values for a 'good' fix. Occasional sensor outages and interfering signals in the ATDnet frequency band might temporarily reduce detection efficiency. In such cases detection of weaker ground flashes and cloud flashes is expected to be more affected as sferics of stronger ground strokes are often detected by all operational sensors. Thus, even in the absence of one or two outstations there are sufficient data available to locate such strokes.

The current outstations are theoretically capable of detecting up to 76 fixes per second making saturation unlikely. However, it is possible that a small fraction of fixes in intense storms is missed due to overlapping sferics of coincident and spatially adjacent fixes.

\section{Lightning location accuracy}

Typical location accuracy of the current ATDnet system is estimated to be around 1$3 \mathrm{~km}$ or better over the UK and 2-10 km for the rest of Europe (Met Office, 2015) whereas for short-range lightning detection systems it is typically a few hundred metres (Anderson and Klugmann, 2014; Schulz et al., 2016). Location accuracy worse than reported above for ATDnet may occur for individual events if there are multiple strokes generating signals that overlap in time. ATDnet has to slice the received signals into short "time windows" to perform a waveform correlation and if there are two peaks within that window it may miscorrelate, which affects the accuracy. Basically the current system correlates the whole waveforms and the timing of the peak of the correlation is the arrival time difference. For example, computed arrival time difference might be wrong by one wave period ( 72.8 $\mu$ s at $13.7 \mathrm{kHz}$ ) for one or more contributing stations. Although there are quality control algorithms that should correct those errors or reject fixes if correction is not possible a minority of affected fixes still makes their way to the final good fix dataset. In addition, sferics of weaker discharges are often detected only by closer outstations (there is no limit in the number of contributing stations for a 'good' fix except that a minimum of 4 stations is needed to produce a fix at all) so a limited number of detecting stations might result in larger than expected location errors. 


\section{New 'UK land area' lightning counts}

Lightning counts have been compiled for the land areas of the UK. Apart from the large land masses of England, Northern Ireland, Scotland and Wales, this includes all islands (Anglesey, Channel Islands, Inner and Outer Hebrides, Isle of Man, Isle of Wight, Orkneys, Scilly Isles, Shetlands). These lightning counts for specific time periods are a much better indicator of the lightning risk facing UK inhabitants as they refer only to lightning within the area where they live, travel and work. Although some people are exposed to the lightning risk when at sea on boats, ships and offshore installations (wind turbines, oil rigs), it is rare for a person to experience a direct injury due to lightning. Elsom and Webb (2014) examined 445 known UK lightning injury or fatality incidents for a recent 25-year period (1988-2012) and with reference to that database there were only three offshore incidents, all within 1-2 km of land. Therefore, it is reasonable for this study to focus on 'UK land area' lightning activity and its potential impact on the UK population.

Table 1 compares the annual counts for the 'UK land area' and the broader 'UK service area' for 2008-2016. Although there is variability in the total counts from year-to-year, the annual lightning count for the 'UK land area' averaged 38\% of the 'UK service area' annual counts. Geographically, the 'UK land area' is about $18 \%$ of the area of the 'UK service area'. In absolute terms, the average annual total lightning count for the 'UK service area' is 156,373 fixes and the 'UK land area' count is 58,833 fixes. The exclusion of parts of continental Europe and the seas between it and the UK from the 'UK land area' counts is one important reason for its lower lightning counts. These areas experience significantly higher annual lightning flash densities than most of the UK (Anderson and Klugmann, 2014).

Table 1

Comparison of the lightning counts for the 'UK land area' and the 'UK service area' for 2008-2016.

Table 1 highlights that 2014 recorded the highest 'UK service area' annual lightning count $(284,219$ fixes) with the 'UK land area' experiencing only $31 \%$ of this total $(86,701$ fixes). In contrast, 2012 recorded the highest annual count for the 'UK land area' with 96,967 fixes which represented $58 \%$ of the 'UK service area' total $(166,789)$. One reason for this is that 2012 experienced exceptionally intense thunderstorms on 28 June (Anderson and Klugmann, 2014) which contributed a remarkable 44,502 lightning counts in $24 \mathrm{~h}$ and is the subject of a case study below.

Figure 4 presents a graph comparing monthly 'UK land area' lightning counts with those for the 'UK service area' from January 2008 to December 2016. As expected, the majority of the lightning in and around the UK occurs during the spring and summer months, and typically the 'UK land area' lightning counts represent less than half of the 'UK service area' monthly totals. Exceptions include the cyclonic months of June and August 2012 when the land-based lightning counts reached two-thirds (48,000 versus 74,000 counts and 35,000 versus 52,000 counts respectively). In contrast, in July 2014 the 'UK land area' recorded only one-quarter of the 'UK service area' counts (29,000 counts versus 126,000 counts). Much of the activity in June 2012 was attributable to one outbreak of severe storms on the 28 June (see case 
study below). August 2012 experienced several days of widespread convection within shallow, slow moving areas of low pressure over or just west of these islands, typified by the case of 5-6 August referred to in a case study below.

Figure 4

Monthly counts for the 'UK land area' and the 'UK service area' for January 2008 to December 2016.

\section{Case studies of exceptional thunderstorm days}

To highlight differences between the two areas of lightning counts, five case studies of one- to four-day duration were selected when there was considerable lightning activity in and around the UK (Figures 1, 5 to 8 ). The lightning counts for the individual 24-hour periods are also provided in table 2. Four summer case studies were selected and one winter example. The latter, the 25 January 2014, was selected to illustrate a day when much of the lightning activity occurred within the 'UK over land' area (Figure 8).

The exceptional lightning counts of 28 June 2012 (Figure 5) were a consequence of a classic 'Spanish plume'. In a generally progressive weather pattern, with a potent upper trough to the west and a strong $(40-50 \mathrm{kn})$ mid-level wind flow from a southwesterly direction, the combination of very high instability (Convectively Available Potential Energy or CAPE) and strong wind shear resulted in violent supercell thunderstorms across the English Midlands (Clark and Webb, 2013). One of these storms produced a severe hail swathe more than $100 \mathrm{~km}$ long. A mesoscale convective system (MCS) also brought extensive disruption to northeast England as a result of lightning strikes and severe flash flooding. The incursion of the very humid, unstable air mass coincided with the time of maximum insolation over central and eastern England. The 28 June 2012 experienced by far the highest lightning activity (44,502 fixes over $24 \mathrm{~h}$ ) within the 'UK land area' amongst the case studies. Figure 5 reveals distinctive bands of 'home grown' thunderstorms generating lightning as they moved from the southwest to the northeast. The substantial swathes of activity over the North Sea were 'extensions' of these thunderstorms as they continued northeastwards.

On 5 August 2012, a slack area of low pressure covered Great Britain; the low then drifted slowly northeastwards on the 6 August. The $500 \mathrm{hPa}$ chart shows a deep long wave upper trough with its axis right over the British Isles. As is common in such situations, convergence zones developed, concentrating convective activity which was essentially 'surface based', that is, related to daytime heating over land of air of modified polar maritime origin (Figure 6). The Nottingham upper air ascent for 0000 UTC on the 6 August indicated that the subsequent maximum temperature of $19^{\circ} \mathrm{C}$ would result in deep instability and generate convection from the boundary layer to the tropopause. Broadly similar weather patterns on several other days in the month (notably the 25 August) also resulted in widespread convective activity developing overland. Generally, on summer days, when convection could easily be triggered 
from the boundary layer by overland insolation (but not sea temperatures), a high proportion of thunderstorm and associated lightning activity would be evident over the land rather than the surrounding seas. In contrast, elevated convection occurs independently of insolation, is more dependent on synoptic forcing, and lightning activity on such days is therefore just as likely to occur over either land or sea areas.

The 22-23 July 2013 episode (Figure 7) was a 'Spanish plume' scenario but in a more blocked weather pattern than the June 2012 case above (e.g. with a greater upper trough extension). Extensive mid-level thunderstorm activity occurred during the evening and night of the 22-23 July as the elevated plume was destabilised. On the following day, storms became focussed on the waving cold front across the north and east of England with a slow-moving multicell thunderstorm depositing more than $100 \mathrm{~mm}$ of rain in the Nottingham area (Suri and Page, 2014; Rothwell, 2014).

The series of thunderstorms from the 17-20 July 2014 began with most lightning activity over the sea before encompassing the UK land area too (Figure 1).

Consequently, the 'UK land area' count represented only $20 \%$ of the total lightning activity recorded in the 'UK service area' compared with the other four case studies where the lightning counts over the 'UK over land' area were $58 \%$ to $77 \%$ of the total activity. This episode was another 'Spanish Plume' situation, evolving rather slowly like that of 22-23 July 2013, but with an even larger upper trough extension extending as far south as Iberia; this tilted the mid-level wind flow to southsoutheast. This scenario was recognised by Lewis and Gray (2010) as the 'Modified Spanish Plume'. From late on 17 July 2014, successive plumes of very warm, humid air moved north from Iberia and France, and were repeatedly overrun by cooler air at higher levels in the atmosphere. High surface temperatures were present (maximum temperature of $32.3^{\circ} \mathrm{C}$ at Gravesend-Swanscombe, Kent, on the 18 July and $28.5^{\circ} \mathrm{C}$ on the 19 July at St James' Park in London) and the result was several outbreaks of widespread thundery activity, each of them across different areas but often including intense thunderstorms (Met Office, 2017). Storms which affected southern UK on the nights of the 17 and 18 July were 'elevated', linked to destabilisation of the plume at mid-levels and unrelated to surface heating overland (hence lightning activity was extensive over sea areas irrespective of sea surface temperatures). This instability was very evident in the Brest upper air ascent for 1200 UTC on 17 July 2014, a few hours before spectacular lightning storms affected southwest England. There was a conspicuous warm 'nose' between 850 and $700 \mathrm{hPa}$ (typical of the 'Spanish Plume') which would have inhibited surface based convection. However, there was a deep layer of latent instability above $700 \mathrm{hPa}$. There was also a moist layer from 700 to $600 \mathrm{hPa}$ capped by much drier air above, giving considerable potential instability. A rippling inner frontal zone was the main focus of thunderstorm activity on the 19 July. An intense supercell thunderstorm occurred over the south Midlands on the afternoon of the 19 July and contributed to the highest 'UK land area' daily count during this four day period (Webb, 2016). Extensive areas of thunderstorms also developed over north-eastern France on the afternoons of both the 18 and 19 July with the associated MCSs clipping southeast England. 
The fifth case study of 25 January 2014 was selected to illustrate a winter example when much of the lightning activity occurred within the UK land area (Figure 8). The event occurred during the exceptionally cyclonic winter of 2013-14. The thunderstorms occurred along a fast-moving cold front as a very strong westerly jet stream was extending eastwards.

Figure 5

ATDnet lightning fixes for the 'UK service area' from 28-29 June 2012 with those occurring within the 'UK land area' distinguished in blue.

Figure 6

ATDnet lightning fixes for the 'UK service area' from 4-6 August 2012 with those occurring within the 'UK land area' distinguished in blue

Figure 7

ATDnet lightning fixes for the 'UK service area' from 22-23 July 2013 with those occurring within the 'UK land area' distinguished in blue

Figure 8

ATDnet lightning fixes for the 'UK service area' for the 25 January 2014 with those occurring within the 'UK land area' distinguished in blue

Table 2

Lightning counts for the five case studies

1 The 'UK service area' from which the media obtained their lightning counts listed in this article's opening paragraph was larger at that time and extended to $5^{\circ} \mathrm{E}$. This explains why they reported "110,000 lightning bolts" for 28 June 2012 and "50,000 lightning bolts" for 23 July 2013.

For the dates covered by the five case studies, the TORnado and storm Research Organisation (TORRO)'s National Lightning Incidents Database lists one fatality, 13 personal-injury incidents and 97 other 'significant' lightning impact incidents (buildings damaged, fires started, animals struck, trees struck and damaged, major electricity supply disruption). These 'significant' (non-personal injury) lightning incidents represent only a fraction of the actual number of incidents as relatively minor damage caused to, say, building roofs and indoor electrical circuits and appliances may not be deemed sufficiently newsworthy to be reported. Nevertheless, the impacts of the lightning may be sufficient for householders to claim for the damaging costs of this 'weather peril' from their insurance company. For example, one insurance company reported during the month of June 2016 they had received more than 200 claims from householders (Boyce, 2016).

\section{Lightning risk to UK inhabitants}


The national risk of lightning resulting in death to people is usually derived from the average number of lightning fatalities in relation to the total population (Elsom, 2015; Holle, 2008, 2016). For example, in the UK for the nine-year period of this study (2008-2016), there were 9 known fatalities recorded by TORRO and listed by government statistical agencies as deaths in which lightning was the underlying cause of death (Elsom and Webb, 2014; Elsom and Webb, 2015a, 2015b; Elsom and Webb, 2017). The average population during this period was 63.7 million so the risk of lightning causing a fatality was $1 / 63.7$ or 0.016 per million population per year $\left(\mathrm{M}^{-1}\right.$ year $\left.^{-1}\right)$ or simply one death per 64 million people. This recent nine-year period experienced relatively few lightning deaths (and did not include three people who were fortunately resuscitated after suffering cardiopulmonary arrest when they were struck by lightning) and it continues the long-term trend of a decreasing number of lightning deaths which began in the nineteenth century. For example, during the corresponding nine-year period a century ago (1908-1916), there were on average 19.7 lightning fatalities for an average population of 41.5 million. This produces a lightning risk of $0.48 \mathrm{M}^{-1}$ year-1 $^{-1}$ or one death per approximately 2 million people. Clearly, the risk of being killed by lightning in the UK has decreased markedly in the past century and even longer for reasons explained by Elsom (2015).

In comparison, the average annual number of fatalities in the USA for the nine-year period 2008-2016 was 28.8 deaths for an average population of 313.1 million, that is, $0.09 \mathrm{M}^{-1} \mathrm{yr}^{-1}$ or simply one fatality per 11 million people (National Weather Service, 2017). This highlights that currently a person in the USA is approximately six times more likely to be killed by lightning than in the UK. This is mostly explained by the much higher lightning incidence (lightning flash rates per $\mathrm{km}^{2}$ per year) over much of central and eastern areas of the contiguous USA. Both the UK and USA currently experience relatively low fatality rates as are also found in Australia, Canada, Japan and many countries in Western Europe. The most unfavourable (worst) rates are found in many countries in Africa and South America where national fatality rates in recent years exceed $0.6 \mathrm{M}^{-1} \mathrm{yr}^{-1}$ (one fatality per 1.7 million people) and in a few countries even exceed $5.0 \mathrm{M}^{-1} \mathrm{yr}^{-1}$ (one fatality per 200,000 people) (Cooper et al., 2016; Elsom and Webb, 2017; Holle, 2008, 2016).

An alternative approach to calculating lightning risk in the UK is to use the new 'UK land area' lightning counts to assess the risk of one person being killed per an average number of lightning strikes. As explained earlier, ATDnet detects about 90 per cent of all cloud-to-ground lightning but also includes 25 per cent of cloud lightning in its totals. However, the 'UK land area' counts provide a much better assessment of the actual number of cloud-to-ground lightning strikes that pose a danger to people on the ground than previously available for the UK. Using the 'UK land area' annual lightning counts for the 2008-2016 period, there was, on average, one person killed for approximately every 59,000 lightning counts during that period. If the 'UK service area' count had been used the risk suggested would have been, on average, one death for approximately every 156,000 counts - a much lower lightning risk and one that has now been shown to be incorrect.

System developments in the future may enable ATDnet to discriminate between cloud-to-ground and cloud lightning in order to record only cloud-to-ground lightning fixes. Until then, the ATDnet 'UK land area' counts are the best available to calculate the risk of lightning resulting in a fatality. Moreover, the current counts in Tables 1 
and 2 may be similar to the actual number of cloud-to-ground lightning strikes if certain assumptions are considered. Cloud-to-ground lightning accounts for around 25 per cent of lightning globally but the percentage varies by latitude, being lowest (about 10 per cent) in the tropics and increasing with latitude. At $60^{\circ} \mathrm{N}$, near the northern limit of the UK, it is estimated that approximately 50 per cent of flashes are cloud lightning and 50 per cent are cloud-to-ground lightning flashes (Rakov and Uman, 2003). Since the ATDnet annual average 'UK land area' count is 58,833 (Table 1 ), this implies this total is comprised of $0.9 * 51,159=46,043$ cloud-to-ground and $0.25^{\star} 51,159=12,790$ cloud lightning detections. In other words, the 'UK land area' count of 58,833 is 15 per cent more than the detected cloud-to-ground lightning strikes (an actual detection count of 51,159 being assumed). However, ATDnet is less sensitive at night, as mentioned earlier, such that the detected cloud-to-ground strikes of 51,159 are underestimated by ATDnet by, say, around 15 to 20 per cent. In other words, this suggests the totals in Tables 1 and 2 approximately represent the total number of actual cloud-to-ground return strokes in the UK. Consequently, using the annual average 'UK land area' total count of 58,833 to calculate the lightning risk to people is justified until advances in the current ATDnet lightning detection system enables it to distinguish between cloud-to-ground and cloud lightning flashes.

The risk of being struck by lightning and killed or injured is much greater than being killed as many more people are injured than die. Typically, the ratio of the average annual number of injuries to deaths is about 14:1 (Elsom and Webb, 2014). A lower ratio of $10: 1$ is suggested for some countries, including the USA (Holle, 2008). The higher UK ratio arises because the UK dataset includes minor lightning injury incidents reported to TORRO such as when a person was struck and injured but did not refer themselves for medical treatment. Such incidents often involved minor electrical effects (e.g. being knocked to the ground; weakness or temporary paralysis of limbs) often caused by the ground current (stepped voltage effect) or surface arcing generated by a nearby lightning strike as well as by unconnected upward discharges (positive streamers). Applying both ratios to the UK and employing the 'UK land area' lightning counts for the 2008-2016 period, indicates the risk of being struck by lightning and experiencing either death or injury was, on average, one person per approximately 4,000 to 5,000 lightning counts $(58,833 /(1+14)$ to $58,833 /(1+10))$.

It would be very interesting if the above UK odds of being killed or injured per average number of lightning counts could be compared with those of other countries, analogous to Elsom (2015) who compared UK lightning fatality rates per million population per year to other countries. However, this would require answers to the same questions raised in this paper about other national lightning location networks and whether or not they included lightning over their surrounding seas and lands outside their national land boundaries. For example, the area covered by the US National Lightning Detection Network (NLDN), delineated as $53^{\circ} \mathrm{N}$ to $20^{\circ} \mathrm{N}$ by $130^{\circ} \mathrm{W}$ to $60^{\circ} \mathrm{W}$ or sometimes $60^{\circ} \mathrm{N}$ to $18^{\circ} \mathrm{N}$ by $130^{\circ} \mathrm{W}$ to $60^{\circ} \mathrm{W}$, includes southern Canada, northern Mexico, Cuba, some Caribbean islands as well as parts of the Pacific Ocean, Atlantic Ocean and Gulf of Mexico. Moreover, the NLDN detection efficiency of detecting all cloud-to-ground and cloud lightning discharges is different to ATDnet. Consequently, national comparisons at this time would not be valid.

\section{Summary}


During periods of exceptional thunderstorm activity over the UK, the media have often cited the number of lightning fixes recorded by the Met Office ATDnet lightning detection system. However, although they attribute these lightning counts to the UK, they have been recorded for a much larger area than the UK (the Met Office 'UK service area'). This exaggerates the lightning activity over the UK and leads to an underestimate of the lightning risk posed to individuals in the UK. New estimates of the UK lightning risk are provided in this paper by counting only lightning activity detected within the 'UK land area'. During the study period (2008-2016), annual lightning count totals ranged from around 21,000 (in 2010) to 97,000 (in 2012). These new annual counts provide a much better estimate of the lightning risk facing the UK population. For the study period, on average, the risk is one lightning death per 59,000 lightning counts and one person, either killed or injured by lightning, per 4,000 to 5,000 lightning counts.

Future developments planned for the Met Office low-cost ATDnet lightning detection system are expected to increase the detection efficiency of weak cloud-to-ground strikes, more readily discriminate between cloud-to-ground and cloud lightning, and measure the polarity and strength of each lightning flash.

\section{References}

Anderson G, Klugmann D. 2014. A European lightning density analysis using 5 years of ATDnet data. Nat. Hazards Earth Syst. Sci., 14: 815-829.

BBC. 2015. As many as 19,525 lightning strikes in the UK over 34 hours.

BBC.co.uk/news, 2 July 2015. http://www.bbc.co.uk/news/uk-33372635 (accessed 8 July 2016)

Blakeslee RJ, Mach DM, Bateman MG, et al. 2014. Seasonal variations in the lightning diurnal cycle and implications for the global electric circuit. Atmos. Res., 135-136: 228-243.

Boyce L. 2016. Lightning damage claims 15 times higher than usual in June insurer says. This is Money.co.uk, www.thisismoney.co.uk/money/mortgageshome/article3656436/Lightning-damage-claims-15-times-higher-usual-month-says-DirectLine.html (accessed 8 February 2017)

Chronis T, Cummins K, Said R, et al. 2015. Climatological diurnal variation of negative CG lightning peak current over the continental United States. J. Geophys. Res.: Atmos., 120: 582-589.

Clark MR, Webb JDC. 2013. A severe hailstorm across the English Midlands on 28 June 2012. Weather, 68: 284-291.

Cooper MA, Andrews CJ, Holle RL, et al. 2016. Lightning-related injuries and safety, In Auerbach PS, Cushing TA and Harris NS (ed.) Auerbach's Wilderness Medicine, Seventh Edition, Philadelphia: Elsevier, chapter 5: pp. 71-117.

Daily Star. 2013. Bang goes summer: Britain zapped by 50,000 lightning bolts. Daily Star, 24 July 2013. http://www.dailystar.co.uk/news/latest-news/328286/Bang-goessummer-Britain-zapped-by-50-000-lightning-bolts (accessed 8 July 2016) 
Elsom DM. 2015. Striking reduction in the annual number of lightning fatalities in the United Kingdom since the 1850s. Weather, 70: 251-257.

Elsom DM, Webb JDC. 2014. Deaths and injuries from lightning in the United Kingdom, 1988-2012. Weather, 69: 221-226.

Elsom DM, Webb JDC. 2015a. Lightning injuries and fatalities in the United Kingdom 2014 and a summary of personal-injury lightning incidents from 1988 to 2014. Int. J. Meteorology, 40 (391): 84-91.

Elsom DM, Webb JDC. 2015b. Lightning impacts in the United Kingdom and Ireland. In Doe, R.K. (ed.) Extreme Weather: Forty Years of the Tornado and Storm Research Organisation (TORRO), Chichester: John Wiley \& Sons, chapter 10, pp. 195-207.

Elsom DM, Webb JDC. 2017. Lightning deaths in the UK: a 30-year analysis of the factors contributing to people being struck and killed. Int. J. Meteorology, 42: in press.

Elsom DM, Webb JDC, Enno SE, Horseman A. 2016. Lightning Fatalities and Injuries in the UK in 2015 and Lightning Safety Advice for Hill and Mountain Walkers. Int. J. Meteorology, 41 (397):105-126.

Enno S-E, Anderson G, Sugier J. 2016. ATDnet detection efficiency and cloud lightning detection characteristics from comparison with the HyLMA during HyMeX SOP1. J. Atmos. Oceanic Technol., 33: 1899-1911.

Gaffard C, Nash J, Atkinson N, et al. 2008. Observing lightning around the globe from the surface. Paper presented at the $20^{\text {th }}$ International Lightning Detection Conference, 2008/ $2^{\text {nd }}$ International Lightning Meteorology Conference, April 2008, Tucson, USA, 12pp.

http://www.vaisala.com/Vaisala\%20Documents/Scientific\%20papers/Observing light ning around the globe from the surface.pdf (accessed 5 June 2016).

Holle R. 2008. Annual rates of lightning fatalities by country. $2^{\text {nd }}$ International Lightning Meteorology Conference, Tucson, AZ, 10pp.

www.vaisala.com/Vaisala\%20Documents/Scientific\%20papers/Annual rates of ligh tning fatalities by country.pdf (accessed 15 January 2017)

Holle R. 2016.The number of documented global lightning fatalities. $24^{\text {th }}$ International Lightning Detection Conference \& $6^{\text {th }}$ International Lightning Meteorology Conference, San Diego, CA, 4pp.

www.vaisala.com/Vaisala\%20Documents/Scientific\%20papers/2016\%20ILDC\%20IL MC/Ron\%20Holle.\%20Number\%20of\%20Documented\%20Global\%20Lightning\%20 Fatalities.pdf (accessed 15 January 2017)

Keogh SJ, Hibbett E, Nash J, et al. 2006 The Met Office Arrival Time Difference (ATD) system for thunderstorm detection and lightning location. Forecasting 
Research Technical Report No. 488, Met Office, 22 pp.

www.wmo.int/pages/prog/www/OSY/Meetings/ET-EGOS Geneva2006/INF-DOC1Thunderstorms.pdf (accessed 22 July 2016)

Lee ACL. 1986a. An experimental study of the remote location of lightning flashes using a VLF arrival time difference technique. Q. J. R. Meteorol. Soc., 112: 203-229.

Lee ACL. 1986b. An operational system for the remote location of lightning flashes using a VLF arrival time difference technique. J. Atmos. Oceanic Technol., 3: 630642.

journals.ametsoc.org/doi/pdf/10.1175/15200426(1986)003\%3C0630\%3AAOSFTR\%3E2.0.CO\%3B2 (accessed 22 July 2016)

Lee ACL. 1989. Ground truth confirmation and theoretical limits of an experimental VLF arrival time difference lightning flash location system. Q. J. R. Meteorol. Soc., 115: $1147-1166$.

Lee ACL. 1990. Bias elimination and scatter in lightning location by the VLF arrival time difference technique. J.Atmos. Oceanic Technol, 7: 719-733.

Lewis, MW, Gray SL. 2010. Categorisation of synoptic environments associated with mesoscale convective systems over the U.K. Atmos. Res. 97: 194-213.

MeteoGroup. 2015. Thunderstorms last night gave around 50,000 lightning strikes across/around the UK in 12 hours. MeteroGroup twitter, 4 July 2015.

twitter.com/weathercast uk/status/617237707283152897, and Facebook, 4 July 2015

https://www.facebook.com/MeteoGroupUK/photos/a.414953196305.193095.501602 16305/10153405294006306/?type=1\&theater (both accessed 8 July 2016)

Met Office, 2012. Record rainfall - April to July 2012. www.metoffice.gov.uk/climate/uk/interesting/april-july2012 (accessed 8 July 2016)

Met Office. 2015 Thunderstorm Location.

www.metoffice.gov.uk/learning/science/first-steps/thunderstorms (accessed 8 July 2016).

Met Office. 2017. Spanish plume event in the UK: 17-21 July 2014. http://www.metoffice.gov.uk/learning/learn-about-the-weather/weatherphenomena/spanish-plume (accessed 16 February 2017)

Nash J, Atkinson NC, Hibbett E, et al. 2006 The new Met Office ATDNET lightning detection system. Paper 2(7) in Proceedings of the WMO Technical Conference on Instruments and Observing Methods, 94, Geneva, Switzerland, 4-6 December, Met Office, 10 pp. www.wmo.int/pages/prog/www/IMOP/publications/IOM-94-

TECO2006/2(7) Nash UK.pdf. (accessed 22 July 2016) 
National Weather Service. 2017. US lightning fatalities 2006-2016. National Oceanic and Atmospheric Administration. www.lightningsafety.noaa.gov/fatalities.shtml (accessed 9 February 2017)

Netweather. 2014. 36,000 lightning strikes in 24 hours and more to come. Netweather.tv, 19 July 2014. http://www.netweather.tv/index.cgi?action=news; storyid $=6025 ;$ sess $=($ accessed 8 July 2016)

Netweather. 2017. Lightning detector - ATD.

http://www.netweather.tv/index.cgi?action=lightning;sess= (accessed 9 June 2017)

Poelman DR, Honore F, Anderson, et al. 2013a. Comparing regional, subcontinental, and long-range lightning location system over the Benelux and France. J. Atmos. Oceanic Technol., 30: 2394-2405.

Poelman DR, Schulz W, Vergeiner C. 2013b. Performance characteristics of distinct lightning detection networks covering Belgium. J. Atmos. Oceanic Technol., 30: 942-951.

QWeather. 2015. Up to 30,000 lightning strikes recorded last night. QWeather, 4 July 2015. https://qweather.co/2015/07/04/up-to-30000-lightning-strikes-recordedlast-night/ (accessed 25 November 2015)

Rakov VA, Uman MA. 2003. Lightning: Physics and Effects. Cambridge University Press, $687 \mathrm{pp}$.

Rodger CJ, Brundell JB, Dowden RL, et al. 2004. Location accuracy of long distance VLF lightning location network. Annales Geophysicae, 22: 747-758.

Rothwell J. 2014. The deluge at Southwell, Nottinghamshire, on 23 July 2013. Weather, 69: 321-322.

Said R. 2017. Towards a global lightning locating system. Weather, 72: 36-40.

Schulz W, Diendorfer G, Pedeboy S, et al. 2016. The European lightning location system EUCLID - Part 1: Performance analysis and validation. Nat. Hazards Earth Syst. Sci., 16: 595-605.

Stall CA, Cummins KL, Krider EP, et al. 2009. Detecting multiple ground contacts in cloud-to-round lightning flashes. J. Atmos. Oceanic Technol, 26: 2392-2402.

Suri D, Page A. 2014. Exceptional rainfall and thunderstorms over Nottinghamshire on 23 July 2013. Weather, 69: 314-321.

The Telegraph. 2012. Weather: record 110,000 lightning bolts strike during 'superstorms'. The Telegraph, 29 June 2012. 
http://www.telegraph.co.uk/news/weather/9365699/Weather-record-110000lightning-bolts-strike-during-superstorms.html (accessed 8 July 2016)

Uman MA. 2008. The Art and Science of Lightning Protection. Cambridge University Press, 240 pp.

Webb JDC. 2016. A supercell thunderstorm in the English south midlands on the afternoon of 19 July 2014. Int. J. Meteorology, 41 (395): 8-23.

Correspondence to Derek Elsom

dmelsom@brookes.ac.uk 
Figure 1

ATDnet lightning fixes for the current 'UK service area' $\left(49^{\circ} \mathrm{N}\right.$ to $63^{\circ} \mathrm{N}$ and $12^{\circ} \mathrm{W}$ to $2^{\circ} \mathrm{E}$ ) for the 96 -hour period from the $17-20$ July 2014 . As part of this study, lightning fixes which occur within the 'UK land area' are shown in blue to highlight that much activity lies outside this area and does not pose a risk to the UK population.

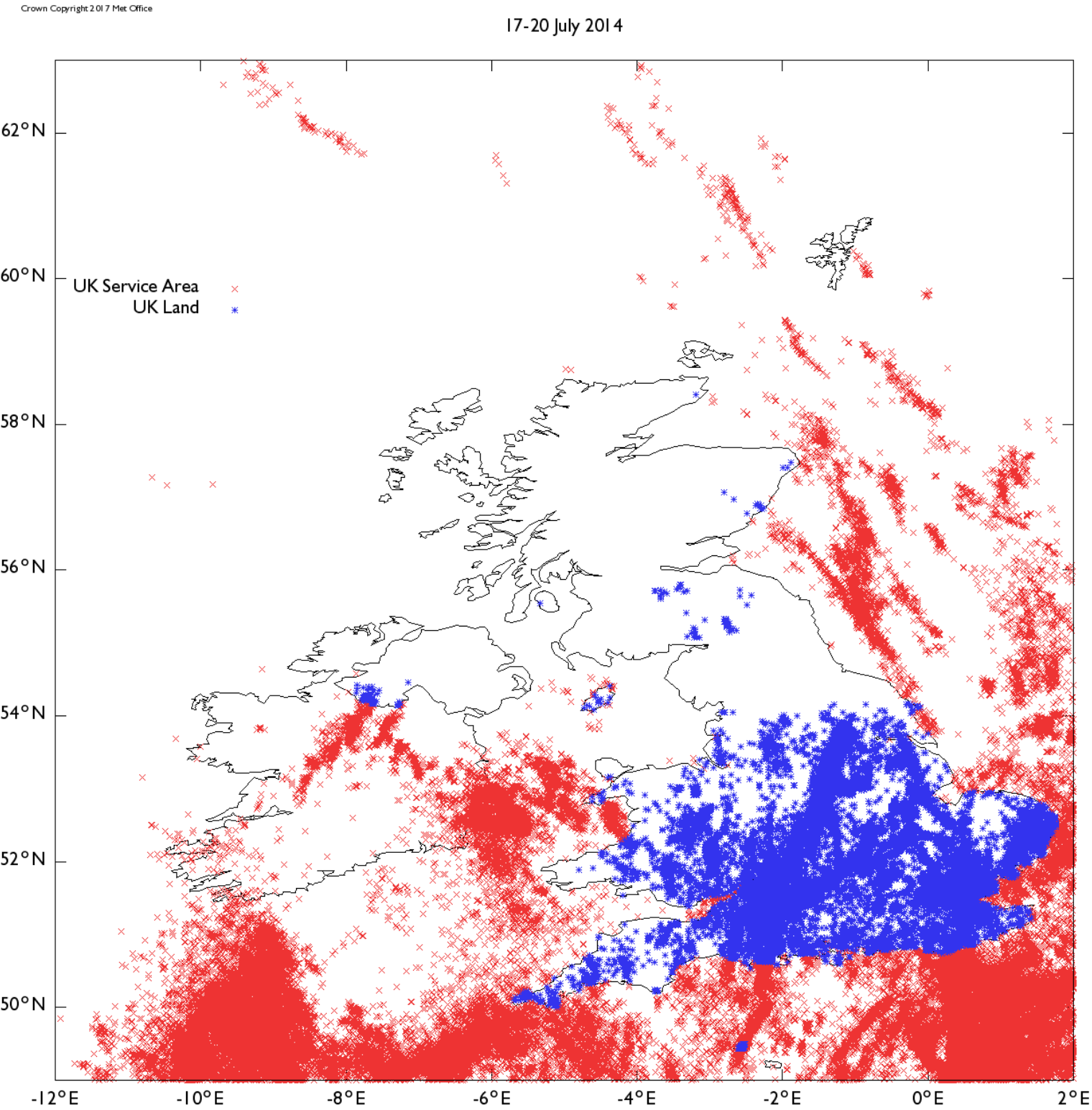


Figure 2

ATDnet's network of ten operational sensors (outstations). Outstation codes: AKR = Akrotiri, $\mathrm{CRO}=$ Croatia, ESK - Eskdalemuir, EXE3 = Exeter, GIB = Gibraltar, HEL $=$ Helsinki, KEF $=$ Keflavik, NOR $=$ Norderney, $\mathrm{PAY}=$ Payerne, $\mathrm{VAL}=$ Valentia

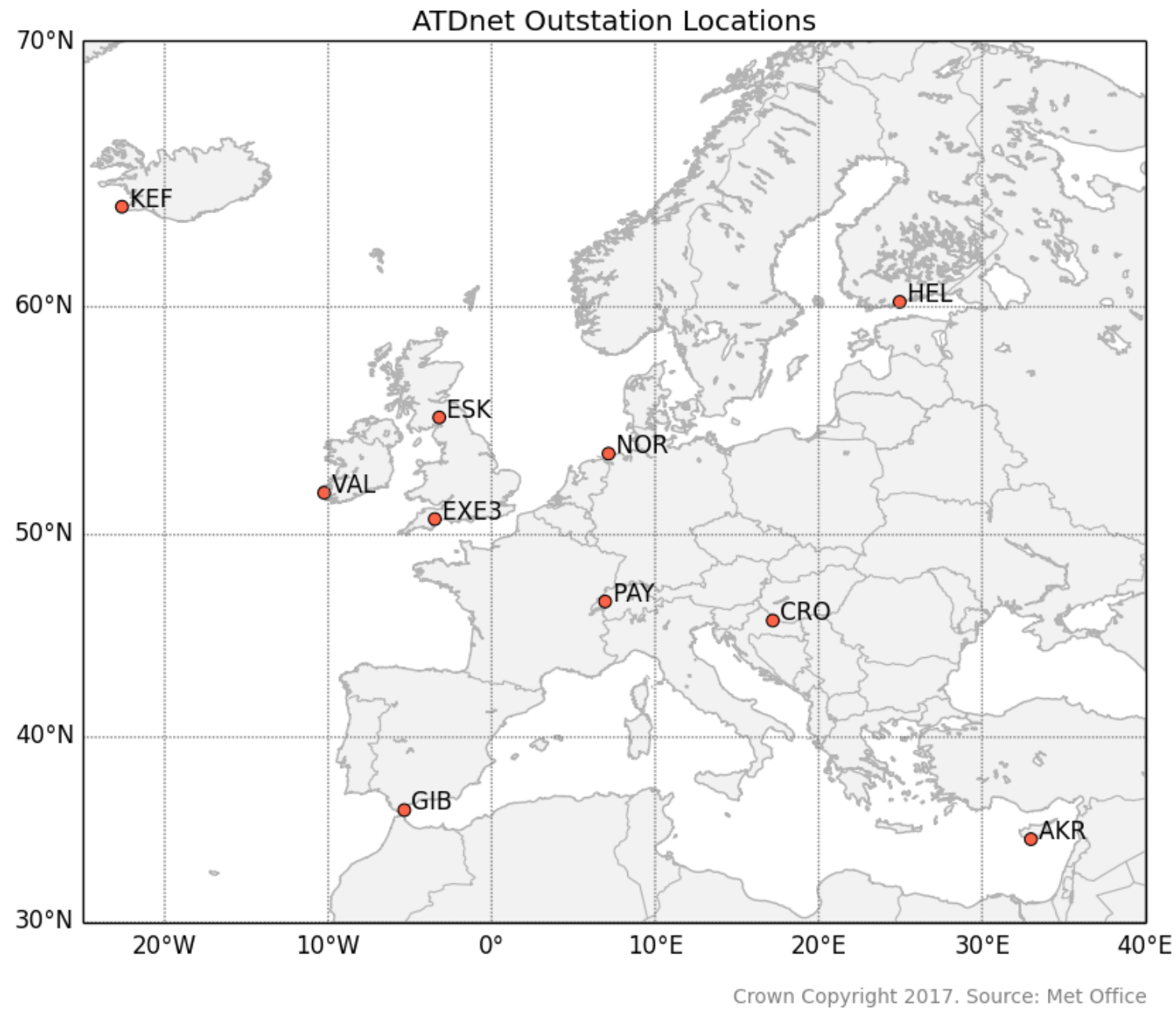


Figure 3

ATDnet outstations use vertical whip antennae that are more sensitive to sferics with vertical polarisation. ATDnet sensor in Keflavik, southwest Iceland (copyright: Met Office)

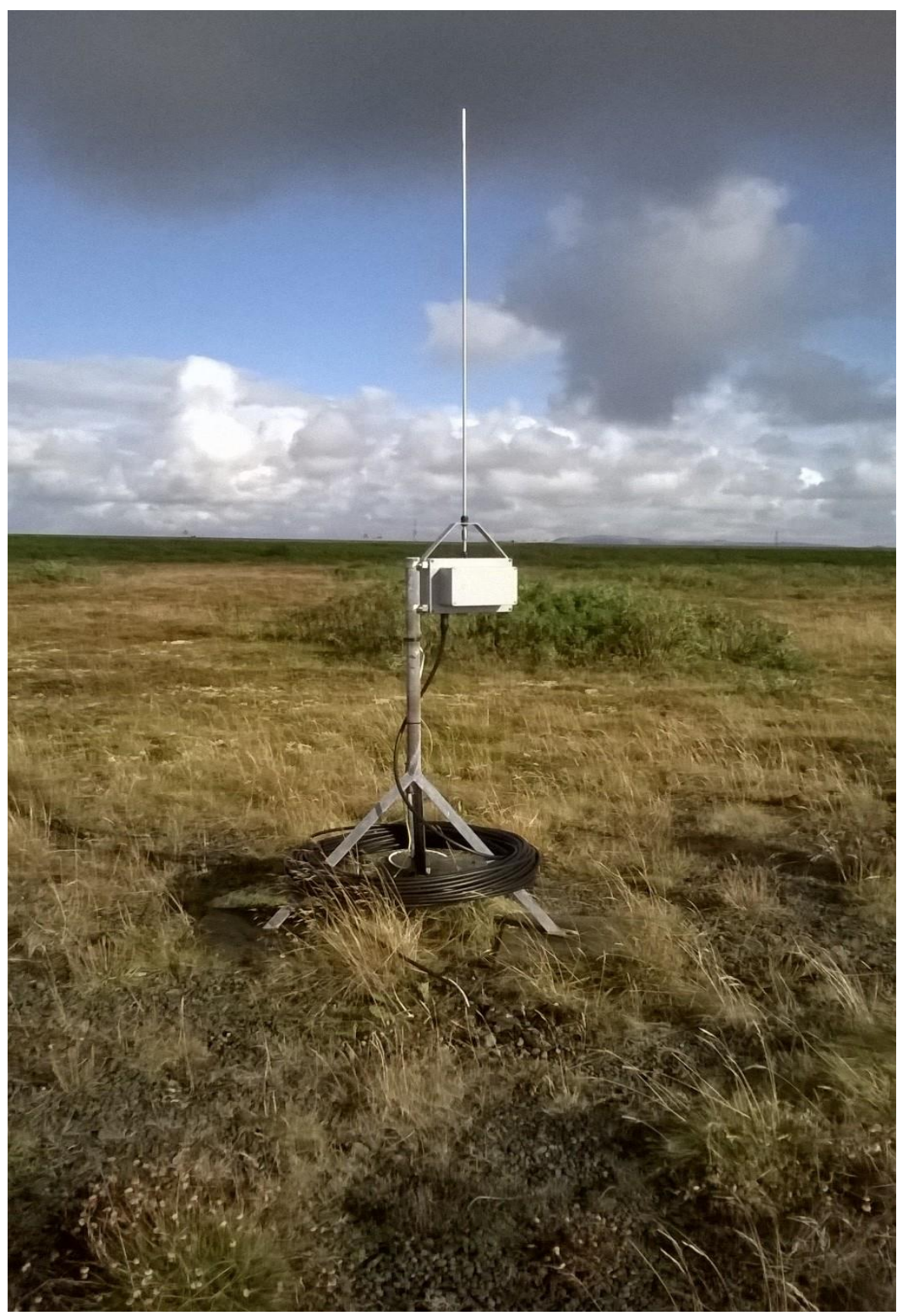


Figure 4

Monthly counts for the 'UK land area' and the 'UK service area' for January 2008 to December 2016.

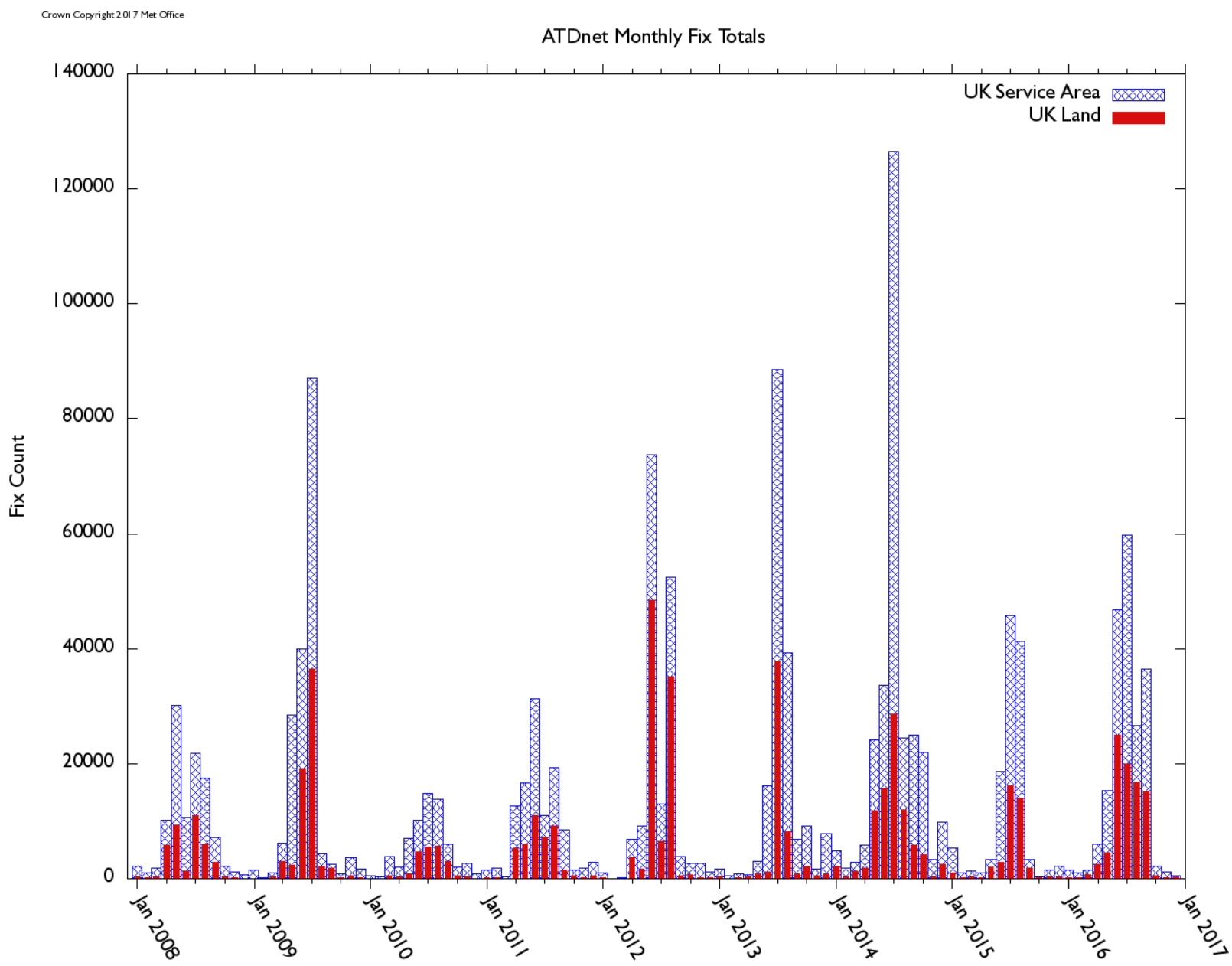


Figure 5

ATDnet lightning fixes for the 'UK service area' from 28-29 June 2012 with those occurring within the 'UK land area' distinguished in blue.

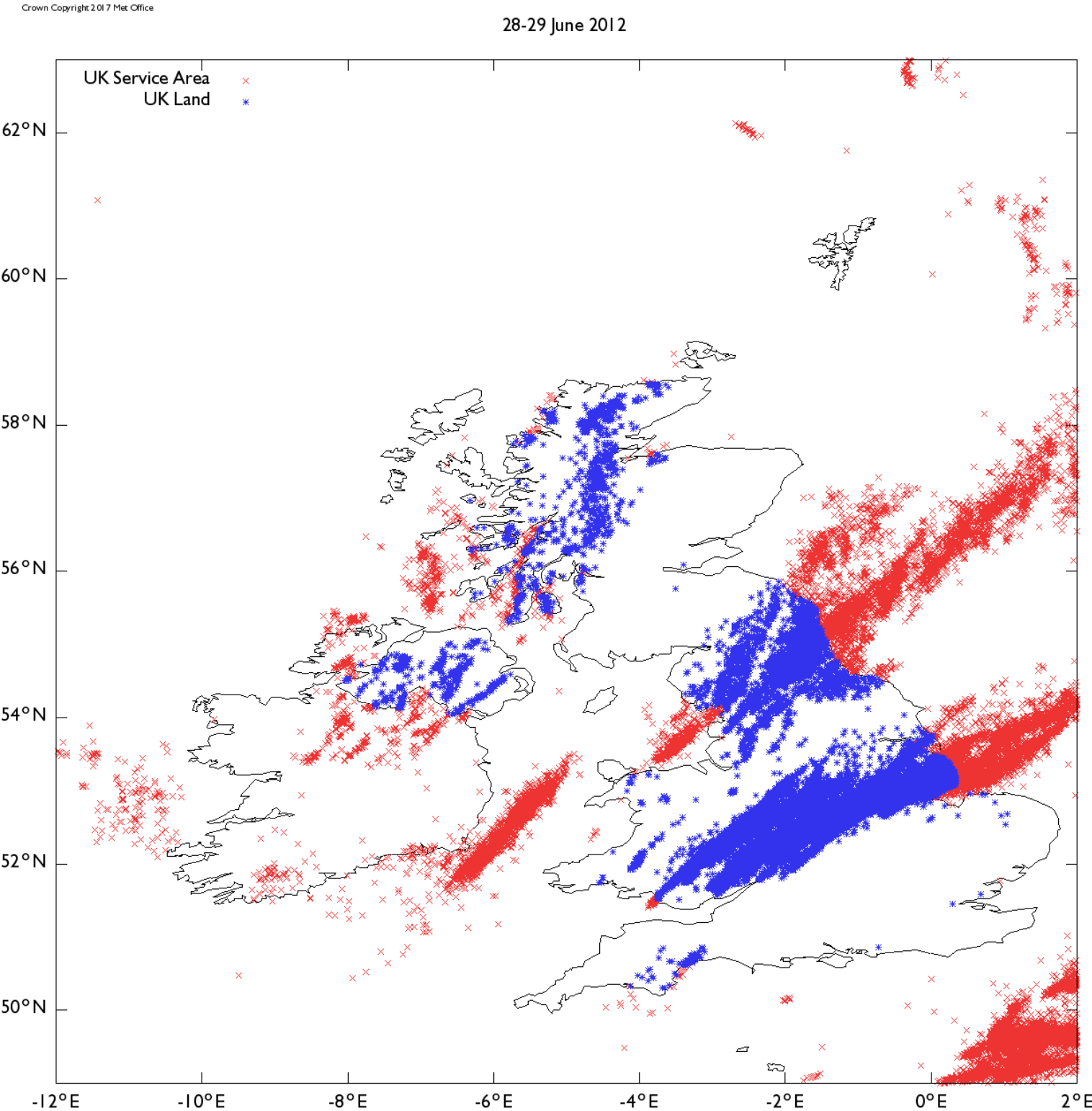


Figure 6

ATDnet lightning fixes for the 'UK service area' from 4-6 August 2012 with those occurring within the 'UK land area' area distinguished in blue

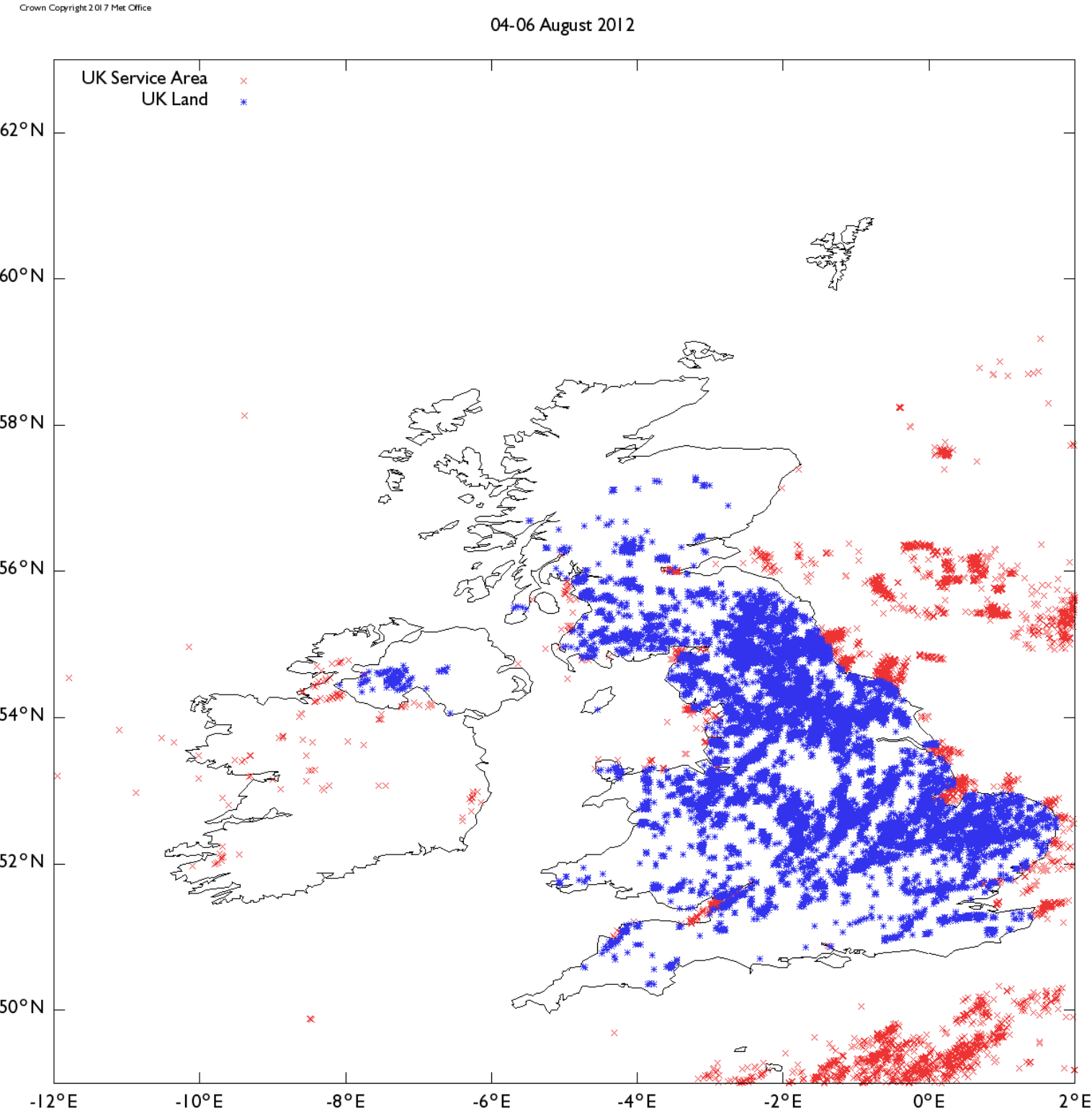


Figure 7

ATDnet lightning fixes for the 'UK service area' from 22-23 July 2013 with those occurring within the 'UK land area' distinguished in blue

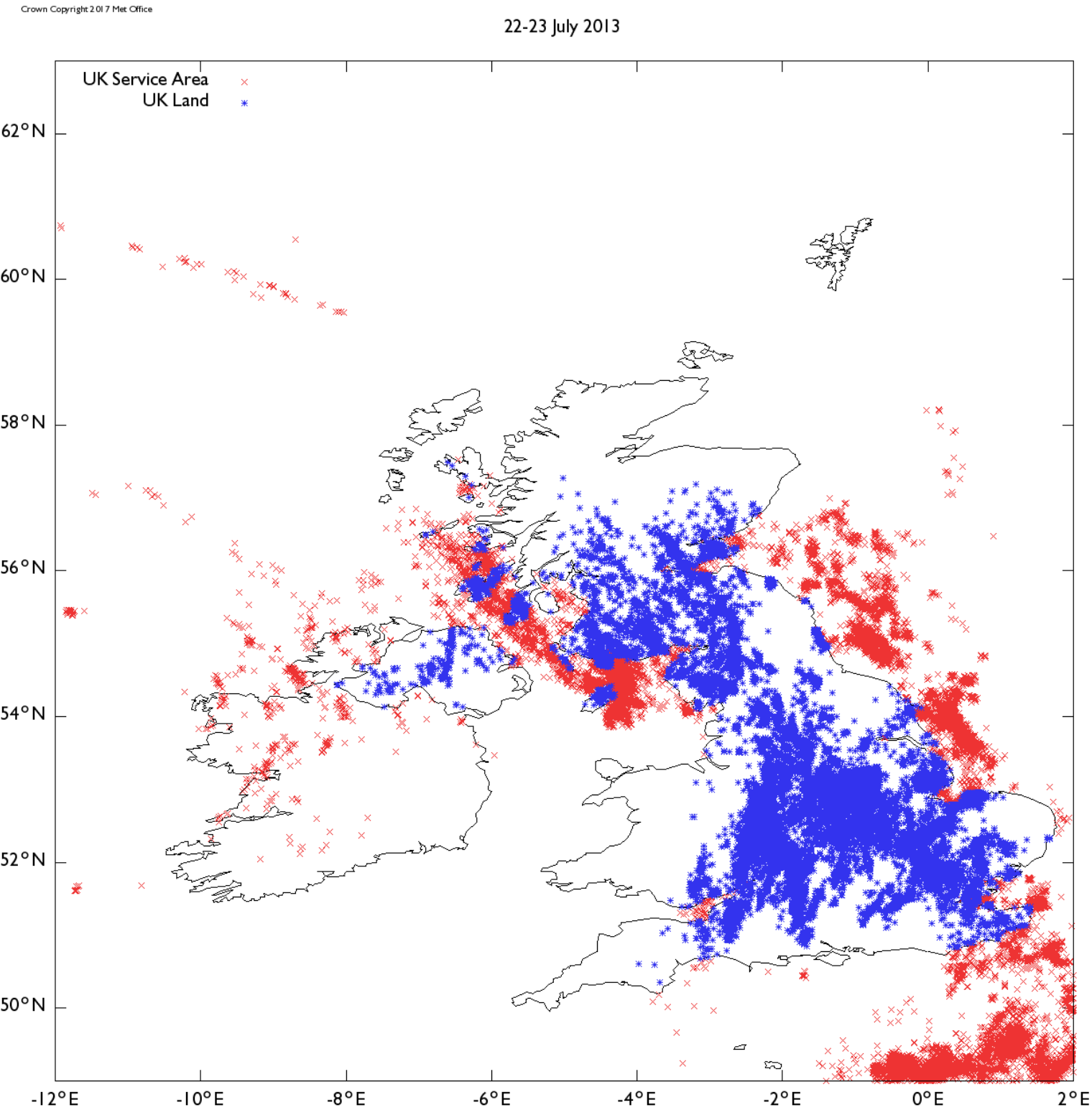


Figure 8

ATDnet lightning fixes for the 'UK service area' for the 25 January 2014 with those occurring within the 'UK land area' distinguished in blue

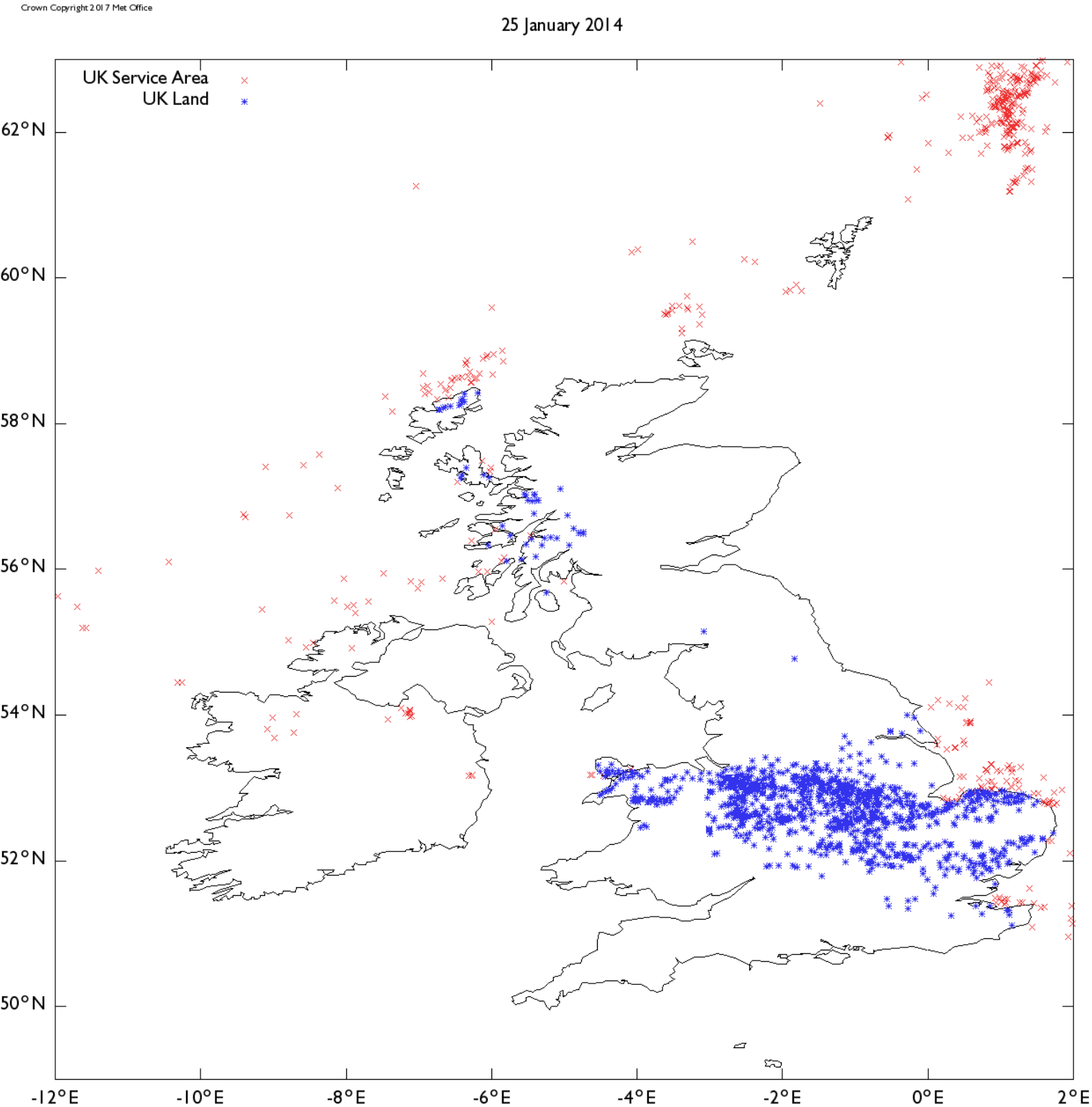


Table 1

Comparison of the lightning counts for the 'UK land area' and the 'UK service area' for 2008-2016.

\begin{tabular}{|c|c|c|c|}
\hline Year & UK land area & UK service area & $\begin{array}{c}\text { \% land area/service } \\
\text { area (rounded to } \\
\text { whole numbers) }\end{array}$ \\
\hline 2008 & 37,564 & 106,344 & 35 \\
\hline 2009 & 66,048 & 177,072 & 37 \\
\hline 2010 & 21,411 & 63,865 & 34 \\
\hline 2011 & 41,747 & 109,198 & 38 \\
\hline 2012 & 96,967 & 166,789 & 58 \\
\hline 2013 & 53,492 & 176,026 & 30 \\
\hline 2014 & 86,701 & 284,219 & 31 \\
\hline 2015 & 39,474 & 125,054 & 32 \\
\hline 2016 & 86,096 & 198,790 & 43 \\
\hline Average annual & 58,833 & 156,373 & 38 \\
\hline
\end{tabular}


Table 2

Lightning counts for the five case studies

\begin{tabular}{|c|c|c|c|c|}
\hline $\begin{array}{c}\text { Case study } \\
\text { dates }\end{array}$ & $\begin{array}{c}\text { UK land } \\
\text { area }\end{array}$ & $\begin{array}{l}\text { UK service } \\
\text { area }\end{array}$ & $\begin{array}{c}\% \text { land } \\
\text { area/service } \\
\text { area (rounded } \\
\text { to whole } \\
\text { number) }\end{array}$ & $\begin{array}{l}\text { Map of } \\
\text { lightning } \\
\text { fixes }\end{array}$ \\
\hline $28 / 06 / 12$ & 44,502 & $64,182^{1}$ & 69 & \multirow{3}{*}{ Figure 4} \\
\hline 29/06/12 & 356 & 608 & 59 & \\
\hline Total & 44,858 & 64,790 & 69 & \\
\hline $04 / 08 / 12$ & 6,347 & 7,100 & 89 & \multirow{4}{*}{ Figure 5} \\
\hline $05 / 08 / 12$ & 5,714 & 7,579 & 75 & \\
\hline $06 / 08 / 12$ & 1,080 & 2,365 & 46 & \\
\hline Total & 13,141 & 17,044 & 77 & \\
\hline $22 / 07 / 13$ & 1,493 & 5,727 & 26 & \multirow{3}{*}{ Figure 6} \\
\hline $23 / 07 / 13$ & 19,266 & $30,353^{1}$ & 63 & \\
\hline Total & 20,759 & 36,080 & 58 & \\
\hline $25 / 01 / 14$ & 1,232 & 1,709 & 72 & Figure 7 \\
\hline $17 / 07 / 14$ & 732 & 26,326 & 3 & \multirow{5}{*}{ Figure 1} \\
\hline $18 / 07 / 14$ & 5,086 & 35,887 & 14 & \\
\hline $19 / 07 / 14$ & 11,735 & 37,258 & 32 & \\
\hline $20 / 07 / 14$ & 3,283 & 4,710 & 70 & \\
\hline Total & 20,836 & 104,181 & 20 & \\
\hline
\end{tabular}

1 The 'UK service area' from which the media obtained their lightning counts listed in this article's opening paragraph was larger at that time and extended to $5^{\circ} \mathrm{E}$. This explains why they reported "110,000 lightning bolts" for 28 June 2012 and "50,000 lightning bolts" for 23 July 2013. 